\title{
Antioxidant and prebiotic effects of a beverage composed by tropical fruits and yacon in alloxan-induced diabetic rats
}

\author{
Ana Paula DIONISIO ${ }^{1 *}$ (D), Luciano Bruno de CARVALHO-SILVA ${ }^{2}$, Nara Menezes VIEIRA³, \\ Nedio Jair WURLITZER ${ }^{1}$, Ana Carolina da Silva PEREIRA ${ }^{4}$, Maria de Fatima BORGES ${ }^{1}$, \\ Deborah dos Santos GARRUTI ${ }^{1}$, Idila dos Santos ARAÚJO ${ }^{1}$
}

\begin{abstract}
The aim of this study was to evaluate the antioxidant and prebiotic effect of a beverage composed by tropical fruits and yacon in alloxan-induced diabetic rats. To obtain the beverage, a Response Surface Methodology was used, with concentration of yacon extract (x1) and the sweetener (x2) added to a mixture of tropical fruits as independent variables, and the sensorial acceptance as response. The optimized beverage showed higher values for antioxidant capacity, measured by ABTS, FRAP and DPPH assays. Thus, the fructooligosaccharides content $(2.32 \pm 0.65 \mathrm{~g}$ FOS/100 g), total phenolic (126.83 $\pm 9.48 \mathrm{mg}$ gallic acid equivalent/100 g) and ascorbic acid (171.64 $\pm 7.31 \mathrm{mg} / 100 \mathrm{~g})$ shows that the beverage contains high levels of these bioactive compounds. In addition, the beverage was tested in vivo, using male Wistar rats, divided into five groups (control, non-treated diabetic, and diabetic treated with 100, 200 or $400 \mathrm{mg}$ of lyophilized beverage $/ \mathrm{kg} / \mathrm{day}$ ). The results showed a promotion of the growth of lactobacilli in cecal material and an increase in catalase activity in the liver, in a dose-dependent manner, showing the prebiotic and antioxidant effects of the beverage in the diabetic model.
\end{abstract}

Keywords: diabetes; oxidative estress; antioxidants; tropical fruits; prebiotics.

Practical Application: In this work we developed a beverage with prebiotic and antioxidant properties.

\section{Introduction}

The International Scientific Association for Probiotics and Prebiotics (ISAPP) defines a prebiotic as "[...] a substrate that is selectively utilized by host microorganisms conferring a health benefit" (Gibson et al., 2017, p. 493). Besides they are naturally present in plant sources like chicory, onion and garlic (Farias et al., 2019; Mohanty et al., 2018; Quigley, 2019), the yacon (Smallanthus sonchifolius) - a Andean tuberous root is one of the most abundant source of fructooligosaccharides (FOS) which exhibit prebiotic properties (Al-Sheraji et al., 2013).

Recently, studies have shown that the yacon possess different biological effects, among immunomodulation (Delgado et al., 2012), antimicrobial (Ojansivu et al., 2011) and antioxidant (Sousa et al., 2015b; Campos et al., 2012). In addition, studies have reported that the ingestion of yacon reduces glycemia and increases the concentration of insulin in the plasma (Park et al., 2009; Aybar et al., 2001; Satoh et al., 2013) and reduces the glycemia of diabetic rats (Dionisio et al., 2015). Moreover, in clinical assays, the yacon have also to be associated with subjective improvements in satiety and reductions in post prandial glucose and insulin concentrations (Adriano et al., 2019; Silva et al., 2017; Kellow et al., 2014 - see also the references listed).

The American Diabetes Association (2010, p. S62) defines diabetes mellitus as "[...] a group of metabolic diseases characterized by hyperglycemia resulting from defects in insulin secretion, insulin action, or both". High blood glucose concentrations promote auto-oxidation of glucose to form free radicals. The generation of free radicals beyond the scavenging abilities of endogenous antioxidant defenses results in macro-and microvascular dysfunction and polyneuropathy (Bajaj \& Khan, 2012).

Cells have evolved highly complex enzymatic (e.g., catalase) and non-enzymatic antioxidant systems (e.g., ascorbic acid and polyphenols), which work synergistically, and in combination with each other, to protect the body against free radical-induced damage. There are several lines of evidence to suggest that antioxidant defenses may be lower in diabetes (Karunakaran \& Park, 2013). In this sense, antioxidants are effective in reducing diabetic complications and may be beneficial either by ingestion of natural antioxidants (Bajaj \& Khan, 2012).

Several tropical fruits have been reported in literature by their functional activities. Camu-camu (Myrciaria dubia McVaugh) is native to the Amazon region, and is considered the richest natural source of vitamin C in Brazil (Cunha-Santos et al., 2019; Chirinos et al., 2010), followed by acerola (Malpighia emarginata D.C.), a fruit recognized by their antioxidant properties due the phenolic and vitamin C composition (Belwal et al., 2018; Rosso \& Mercadante, 2007). Cashew-apple (Anacardium occidentale L.) and yellow 
mombim (Spondias mombim L.) belongs to the Anacardiacea family, and are important fruits in the Northeast region of Brazil, rich in bioactive compounds and responsible for a sweet and sour taste (Rufino et al., 2010). Furthermore, acai (Euterpe oleracea Mart.) is one of the most popular fruit from Amazon and widely used in the world due to recognized antioxidant properties (Yamaguchi et al., 2015).

Pereira et al. (2015) evaluated the synergistic, antagonistic and additive effects of different tropical fruits (camu-camu, cashew-apple, acerola, yellow mombim and acai), with aim to obtain a beverage with high levels of bioactive compounds. Furthermore, the beverage was evaluated in vivo, and shown to be effective in endogenous antioxidant defense of health Wistar rats, altering the catalase (CAT) and glutathione peroxidase (GPx) activities, and decreasing the lipid peroxidation in liver and serum in the animals (Pereira et al., 2014). Moreover, the antimutagenic and antiproliferative activities were also demonstrated by Carvalho-Silva et al. (2014) using health Swiss mice.

Considering the positive effects in the antioxidant status of this tropical fruit beverage in health models, and the importance of the antioxidants compounds and FOS for diabetes, the aim of this work was to evaluate the prebiotic and antioxidant effects of a beverage composed by tropical fruits (rich in antioxidant compounds) and yacon (source of FOS), in alloxan-induced diabetic rats.

\section{Materials and methods}

\subsection{Chemical and reagents}

The reagents used were potassium persulphate from Acrós Organics and ferrous sulphate from Vetec ${ }^{\mathrm{TM}}$. HPLC grade water was prepared from distilled water using a Milli-Q system (Millipore Lab., Bedford, MA, USA). All other chemicals were purchased from Sigma Aldrich Canada Ltd. (Oakville, ON, Canada).

\subsection{Tropical fruits and yacon}

Camu-camu frozen pulp (Myrciaria dubia (H. B. K.) McVough) was purchased at the local market in Belém - Pará - Brazil. The frozen pulp of yellow mombin (Spondias mombin L.), acai (Euterpe oleracea Mart.), acerola (Malpighia emarginata D.C.), cashew apple (Anacardium occidentale L.) and pineapple (Ananas comosus L. Merr), were obtained in the local market in Fortaleza Ceará - Brazil. The yacon (Smallanthus sonchifolius) was obtained in a local market at Fortaleza, Ceará State, Brazil. Then, yacon extracts were processed as reported by Dionisio et al. (2013). All the pulps and the yacon extract were stored at $-18{ }^{\circ} \mathrm{C}$ for further use in the experimental design.

\subsection{Beverage formulations}

The blend formulation was obtained in a statistical planning as reported previously (Pereira et al., 2015), composed by $10 \%$ acerola, 5\% acai, $5 \%$ yellow-mombim, 5\% cashew apple, 5\% camu-camu, $20 \%$ pineapple and $50 \%$ water. However, in the present experiment, the water was replaced by yacon extract in different concentrations to provide the prebiotic characteristic of the beverage (due to its FOS constituents). For the prebiotic beverage, a two-level $\left(2^{2}\right)$ central composite design (CCD) was employed to optimize the values of sensorial acceptance (dependent variable) using the concentration of yacon (50 to $70 \%)$ and concentration of sweetener (stevia, 0.01 to $0.10 \%$ ) as independent variables. All the experiments were carried out in order to have a random selection method to minimize the effect of unexplained variability in the responses due to systematic errors. The analysis of variance (ANOVA) was applied to validate the model, and the regression coefficients were then used to generate response surfaces. The $P<0.05$ was considered to be statistically significant. All results were performed using Statistica 7.0.

\subsection{Sensorial analysis}

The sensory evaluation of acceptance was carried out with fifty untrained panelists (63\% female, $82 \%$ aged $18-45$ years), as suggested by Meilgaard et al. (2006) in the laboratory test, using nine-point structured hedonic scales (1: 'disliked extremely' to 9: 'liked extremely') (Souza et al., 2019). The order of presentation of the samples followed balanced order. This sensory test procedure was approved by the Research Ethics Committee of the Ceará State University, under protocol number 11044529-5.

\subsection{Prebiotic beverage}

The optimized prebiotic beverage was prepared by mixing the blend formulation (50\%), yacon extract (50\%) and $0.07 \%$ of stevioside. An Armfield FT74 tubular heat exchanger unit was used to pasteurize the prebiotic beverage after preparation. The beverage, placed in a feed tank, was pumped through the heat exchanger to achieve the treatment condition $\left(85^{\circ} \mathrm{C}\right.$ for $\left.90 \mathrm{~s}\right)$. After heating, the samples were cooled in an ice/water bath, packed, and then stored under $-18 \pm 2{ }^{\circ} \mathrm{C}$ until needed for chemical analyses. For the in vivo assay, the beverage was lyophilized immediately after thermal processing and stored at $-18 \pm 2{ }^{\circ} \mathrm{C}$ prior to use.

\subsection{Prebiotic beverage characterization}

\section{Physico-chemical analyses}

The color was performed in a Minolta Colorimeter (Model CR-400, Konica Minolta Sensing, Inc., Osaka, Japan), with results based on three color coordinates: $L^{*}$ (whiteness or brightness/darkness), $\mathrm{a}^{*}$ (redness/greenness), and $\mathrm{b}^{*}$ (yellowness/blueness). The acidity (\% citric acid) was determined according to the method of Instituto Adolfo Lutz (2008), while the $\mathrm{pH}$ values were obtained using a $\mathrm{pH}$ meter (Hanna Instruments, Romania) (Association of Official Analytical Chemists, 2005). The soluble solids content ( ${ }^{\circ}$ Brix) was determined using a refractometer at $20.0 \pm 0.5^{\circ} \mathrm{C}$, as recommended by Association of Official Analytical Chemists (2005). All analyses were carried out in triplicate.

\section{Microbiological analyses}

The presence of total coliform and Escherichia coli in the prebiotic beverage was evaluated according to the Feng et al. (2013). Mesophilic aerobic, mold and yeast counts, and the safety microbial parameters Salmonella spp. according to the Andrews et al. (2016). Analyses were carried out according to 
the methodology described by FDA's Bacteriological Analytical Manual, and the results were expressed as colony-forming units per milliliter $(\mathrm{cfu} / \mathrm{mL})$ of product. These analyses were carried out in triplicate.

\section{Total Antioxidant Capacity (TAC), Total Polyphenols (TP) and Fructooligosaccharides content (FOS)}

The total antioxidant capacity was measured by the ABTS, FRAP and DPPH methods. For antioxidant extraction, the procedure developed by Larrauri et al. (1997) was used. The samples were extracted sequentially with $4 \mathrm{~mL}$ of methanol/water $(50: 50, \mathrm{v} / \mathrm{v})$ at $25{ }^{\circ} \mathrm{C}$ for $1 \mathrm{~h}$, centrifuged at $25^{\circ} \mathrm{C}, 400 \mathrm{~g}$ for $15 \mathrm{~min}$, and the supernatant was recovered. Then, $4 \mathrm{~mL}$ of acetone/water $(70: 30, \mathrm{v} / \mathrm{v})$ were added to the residue at $25^{\circ} \mathrm{C}$, extracted for $60 \mathrm{~min}$, and centrifuged at the same condition. Methanolic and acetonic extracts were combined, and added to $10 \mathrm{~mL}$ with distilled water.

The free radical scavenging activity was determined by the DPPH method (Brand-Williams et al., 1995); the ABTS-+ assay was based on a method developed by Miller et al. (1993) and, for the FRAP assay, the procedure described by Benzie \& Strain (1996). All the methods were used with the modifications suggested by Rufino et al. (2010). The results of DPPH method were expressed as the concentration of antioxidant required to reduce the original amount of free radicals by $50 \%\left(\mathrm{EC}_{50}\right)$ and the values were expressed as g prebiotic beverage per $g$ of DPPH. For the ABTS and FRAP assay, the results were expressed as $\mu \mathrm{M}$ Trolox and $\mu \mathrm{M} \mathrm{Fe}_{2} \mathrm{SO}_{4} / \mathrm{g}$ of prebiotic beverage, respectively. Thus, the total polyphenols (TP) was determined by the Folin-Ciocalteu method (Obanda et al., 1997) and the results were expressed as mg GAE (gallic acid equivalent)/100 g of prebiotic beverage. The fructooligosaccharides were determined as described by Horwitz et al. (2010), and the results expressed as $\mathrm{g}$ FOS/100 $\mathrm{g}$ of prebiotic beverage.

\subsection{Prebiotic beverage: in vivo studies}

\section{Animals and experimental design}

The present animal study was carried out following the guidelines in the use of animals for experimental purpose after due approval from the Research Ethics Committee on the use of animals at the Federal University of Alfenas/UNIFAL-MG (Protocol no. 528/2013). Male rats weighing $90 \pm 5 \mathrm{~g}$ were kept under standard laboratory conditions of temperature $\left(22 \pm 2{ }^{\circ} \mathrm{C}\right)$, relative humidity (52 $\pm 5 \%$ ), and $12 \mathrm{~h}$ light-dark cycle. Diet and water were provided ad libitum. For diabetes induction, overnight fasted rats received intraperitoneal injection (i.p.) of alloxan $(120 \mathrm{mg} / \mathrm{kg})$, followed by an aqueous solution of $10 \%$ sucrose for $24 \mathrm{~h}$. After four days, the glycemia was measured and all rats that presented glucose levels higher than $200 \mathrm{mg} / \mathrm{dL}$ were considered positive diabetic induced. The lyophilized prebiotic beverage and saline solution ( $\mathrm{NaCl} 0.9 \%$, for the control groups) were administered daily by gavage $(0.5 \mathrm{~mL} / 100 \mathrm{~g}$ body weight) for 30 days. Rats ( $n=30$, six animals for group) were divided into the following groups: (1) negative control (healthy animals receiving saline solution); (2) positive control (diabetic animals receiving saline solution); (3) diabetic animals receiving $100 \mathrm{mg}$ of prebiotic beverage per kg body weight; (4) diabetic animals receiving $200 \mathrm{mg}$ of prebiotic beverage per $\mathrm{kg}$ body weight and (5) diabetic animals receiving $400 \mathrm{mg}$ of prebiotic beverage per $\mathrm{kg}$ body weight.

Nutritional parameters such as weight gain and food consumption were collected three times a week. The blood glucose levels were measured nine times. At the end of the experiment, rats were killed, and blood was collected in heparinised tubes (20 U heparin/mL blood) and centrifuged at $1900 \mathrm{~g}$ for $10 \mathrm{~min}$. The separated plasma was stored at $-80{ }^{\circ} \mathrm{C}$ until processed. An aliquot from caecal content was used for microbial analyses and the liver was perfused with saline solution $(0.9 \% \mathrm{w} / \mathrm{v})$, collected and immediately frozen at $-80^{\circ} \mathrm{C}$.

\section{Catalase activity}

Catalase activity (CAT) was measured in liver tissue, and the methodology used is in according to Aebi (1984). Briefly, the activity was assayed at $25^{\circ} \mathrm{C}$ by a method based on the disappearance of $10 \mathrm{mM} \mathrm{H}_{2} \mathrm{O}_{2}$. The decomposition of $\mathrm{H}_{2} \mathrm{O}_{2}$ by CAT contained in the samples a first-order kinetic and changes in absorbance were measured after addition of $\mathrm{H}_{2} \mathrm{O}_{2}$, and then at $10 \mathrm{~s}$ intervals, in a total of $60 \mathrm{~s}$.

\section{Lactobacilli analysis of caecal material}

To measure the prebiotic effect of the beverage, one gram of caecal material was transferred into a sterile tube and mixed with $9 \mathrm{~mL}$ of sterile saline phosphate solution (PBS, Sigma Aldrich) and then serially diluted (from $10^{-1}$ to $10^{-7}$ ) in a Rogosa Agar SL medium (Becton Dickinson, USA). Incubation was performed at $35{ }^{\circ} \mathrm{C}$ under anaerobic conditions using the anaerobic jar with Anaerocult A (Merck, Darmstadt Germany). After $48 \mathrm{~h}$ incubation, the number of colonies was recorded as $\log _{10} \mathrm{cfu} / \mathrm{g}$ of wet sample.

\subsection{Statistical analyses}

The results of the optimization of the beverage were analyzed using the Statistic $7.0(P<0.05)$. For the in vivo assays, the GraphPad Prism 4.0 for Windows (San Diego, CA, USA) was used. A one-way analysis of variance (ANOVA) and Tukey test $(P<0.05)$ were applied to the results.

\section{Results and discussion}

\subsection{Optimization of the beverage formulation}

The Table 1 shows the results obtained for the sensorial acceptance for all formulations tested. The values obtained ranged of 4.5 to 7.0 , which corresponded to "dislike slightly" to "like moderately". Considering the effect of each parameter tested (sweetener or yacon extract concentration, in \%), only the sweetener presented a significant effect $(P<0.05)$, in both linear and quadratic parameters.

Analysis of variance for the dependent variables indicated that the response surface model developed was adequate $\left(\mathrm{R}^{2}=82.57\right)$. The coefficient of determination $\left(\mathrm{R}^{2}\right)$ value is quite high, indicating that a high proportion of variability was 
Table 1. Experimental design and results in RSM study.

\begin{tabular}{cccc}
\hline Run $^{\circ}$ & Sweetener $_{1}$ & Yacon extract $x_{2}$ & $\begin{array}{c}\text { Sensorial } \\
\text { acceptance }\end{array}$ \\
\hline 1 & -1 & -1 & 6.1 \\
2 & +1 & -1 & 6.3 \\
3 & -1 & +1 & 6.0 \\
4 & +1 & +1 & 6.6 \\
5 & -1.21 & 0 & 4.5 \\
6 & +1.21 & 0 & 6.8 \\
7 & 0 & -1.21 & 6.6 \\
8 & 0 & +1.21 & 6.8 \\
9 & 0 & 0 & 6.9 \\
10 & 0 & 0 & 7.0 \\
11 & 0 & 0 & 6.9 \\
\hline
\end{tabular}

Table 2. ANOVA for response surface quadratic model.

\begin{tabular}{lccccc}
\hline \multicolumn{2}{c}{ Variation source SS } & $d f$ & SM & $F_{\text {calc. }}$ & $p$-value \\
\hline Regression & 4.2 & 2 & 2.1 & 18.9 & 0.00092 \\
Residues & 0.9 & 8 & 0.1 & & \\
Lack of fit & 0.9 & 6 & 0.1 & 44.4 & 0.02220 \\
Pure error & 0.0 & 2 & 0.0 & & \\
Total & 5.1 & 10 & & & \\
\hline
\end{tabular}

$\mathrm{SS}=$ Sum of squares; $d f=$ Degrees of freedom; $\mathrm{SM}=$ Square Means; $F_{\text {calc. }}=$ F-Calculated; p-value $=$ Calculated probability.

explained by the data and that the RSM model was adequate (Table 2). Although F-value was higher than Ftab (Fcalc = 18.9; Ftab $=4.46$ ), the lack of fit, which measures the fitness of the model, resulted in a significant $F$-value. However, the pure error is approximately zero, and for this reason the Fcalc presents high value, and consequently, is higher than the Ftab (Fcalc = 44.4; $\mathrm{Ftab}=19.33)$. Analysis of variance (ANOVA) was performed considering only the statistically significant $(P<0.05)$ variables, and a valid model was defined by Equation 1 :

Sensorial acceptance $=6.84+0.51 \times 1-0.59 \times 1^{2}$

where: $\mathrm{x} 1$ is coded variable (sweetener, in \%).

According to Figure 1, the maximal sensorial acceptance of the beverage was obtained using $0.07 \%$ of sweetener. Considering that the yacon extract did not present statistical significance $(P>0.05)$ in the range tested (50 to $70 \%)$, the cost of yacon and the legislation (that allow the use of $50 \%$ of water), the condition defined by the authors as $50 \%$ of yacon extract and $0.07 \%$ of sweetener.

\section{Prebiotic beverage characterization}

The prebiotic beverage presents $9.40 \pm 0.10^{\circ} \mathrm{Brix}$; acidity of $0.69 \pm 0.00$ (\% citric acid); and the following color coordinates: $28.16 \pm 0.75\left(L^{\star}\right), 9.52 \pm 0.13\left(\mathrm{a}^{\star}\right)$ and $10.13 \pm 0.37\left(\mathrm{~b}^{\star}\right)$. Furthermore, the beverage presents lower value of $\mathrm{pH}(3.38 \pm 0.01)$. This result was expected, since the beverage were composed by fruits such as camu-camu and acerola, recognized by the high ascorbic acid contents (Cunha-Santos et al., 2019; Akter et al., 2011; Mezadri et al., 2008).

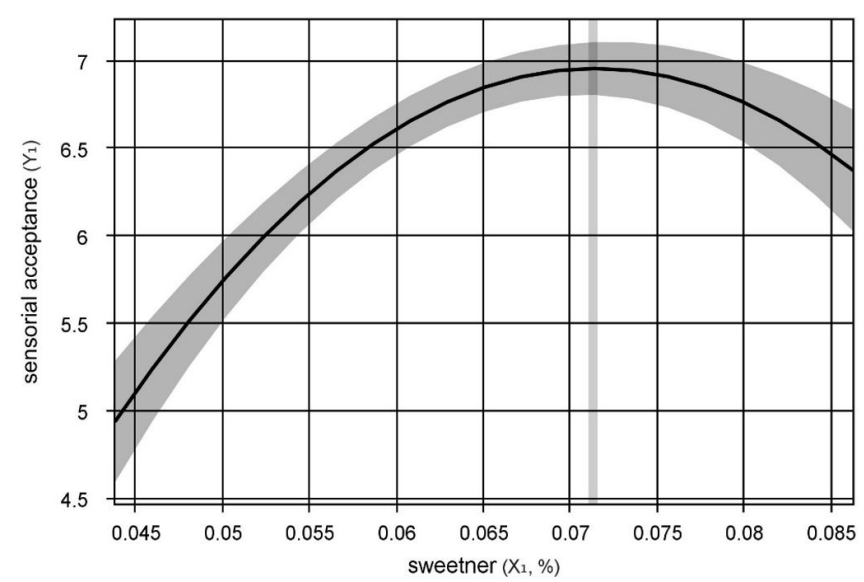

Figure 1. Effect of the sweetener concentration (\%) in the sensorial acceptance of the prebiotic beverage, using $50 \%$ of yacon extract.

The total phenolic compounds ( $126.83 \pm 9.48 \mathrm{mg} \mathrm{GAE} / 100 \mathrm{~g})$ and ascorbic acid contents $(171.64 \pm 7.31 \mathrm{mg} / 100 \mathrm{~g})$ were also determined in the beverage. These values are in accordance with the reports of Pereira et al. (2015), using similar composition of tropical fruits, however, without yacon. The values obtained by the authors were $103.01 \pm 5.96 \mathrm{mg} \mathrm{GAE} / 100 \mathrm{~g}$ and $155.46 \pm 2.07 \mathrm{mg} / 100 \mathrm{~g}$ for polyphenols and ascorbic acid, respectively. In addition, the total antioxidant activity of the prebiotic beverage were $10.57 \pm 0.50 \mu \mathrm{M}$ Trolox; $33.45 \pm 0.41 \mu \mathrm{M}$ $\mathrm{Fe}_{2} \mathrm{SO}_{4}$ and $866.36 \pm 25.30 / \mathrm{g}$ of prebiotic beverage for ABTS, FRAP and DPPH method, respectively. These values are considerable high, and show the antioxidant potential of the beverage, which contributed to their functional properties.

As mentioned before, the yacon were added into beverage due the high FOS content. Considering this, the FOS was measured in the product. The values obtained were $4.64 \pm 0.13$ of FOS/200 mL that represents a portion of beverage. This value is about two times higher than that required by Brazilian claim for products with functional properties (Brasil, 2019), considering a minimum of $2.5 \mathrm{~g}$ of FOS for portion of a prebiotic beverage. In this case, the permitted claim is "FOS as prebiotics contribute to a balance/equilibrium of the intestinal flora. Their consumption should be associated with a balanced diet and a healthy life-style".

\subsection{In vivo study}

Non-significant differences $(P>0.05)$ among the groups that received the prebiotic beverages and their effects on diet consumption when compared to positive control (diabetic animals who received saline solution) are presented in Figure 2. Besides the diet consumption of all diabetic animals was higher than the health animals (negative control), there are no statistical difference $(P>0.05)$ in the weight gain in all treatments studied (see Figure 2).

Several papers report the potential of yacon in the glycemia control for diabetic animals or humans (Park et al., 2009; Aybar et al., 2001; Dionisio et al., 2015; Kellow et al., 2014). Unfortunately, the beverage showed no statistical effect $(P>0.05)$ 

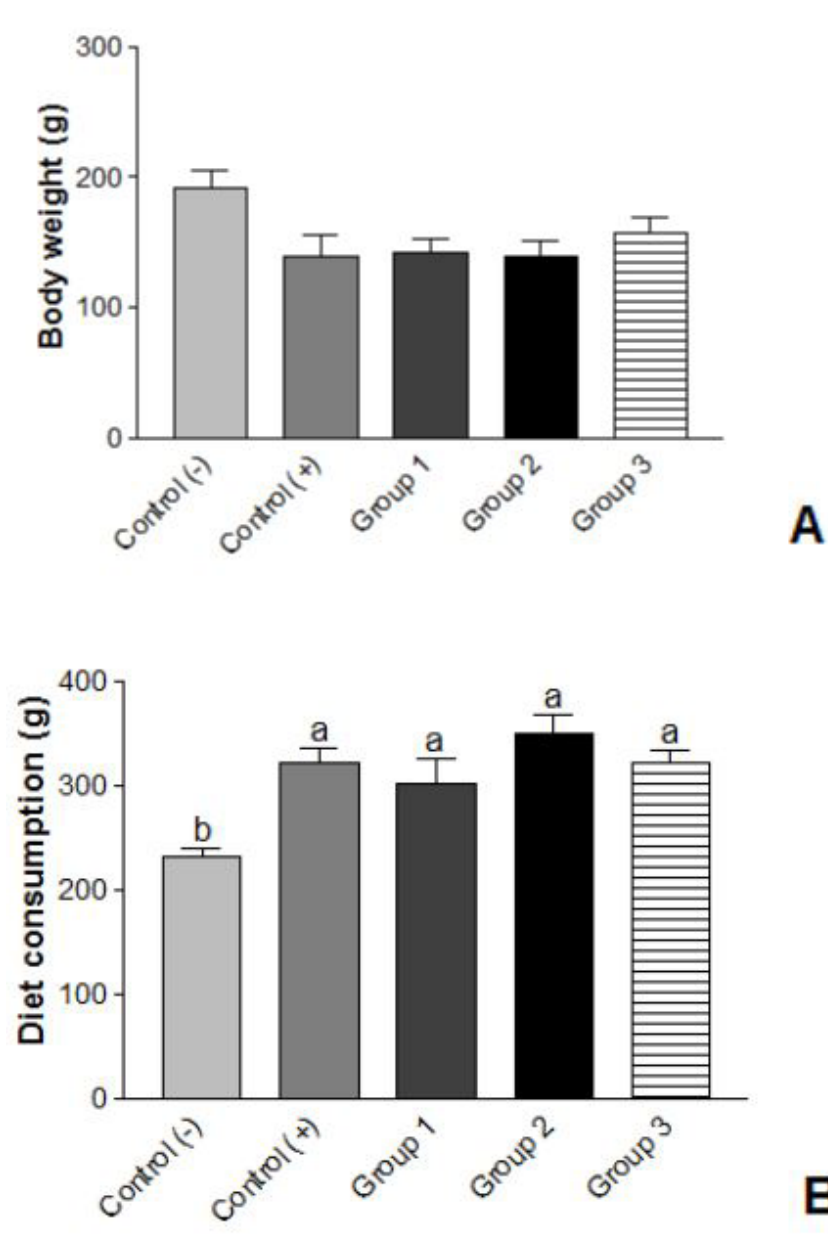

B

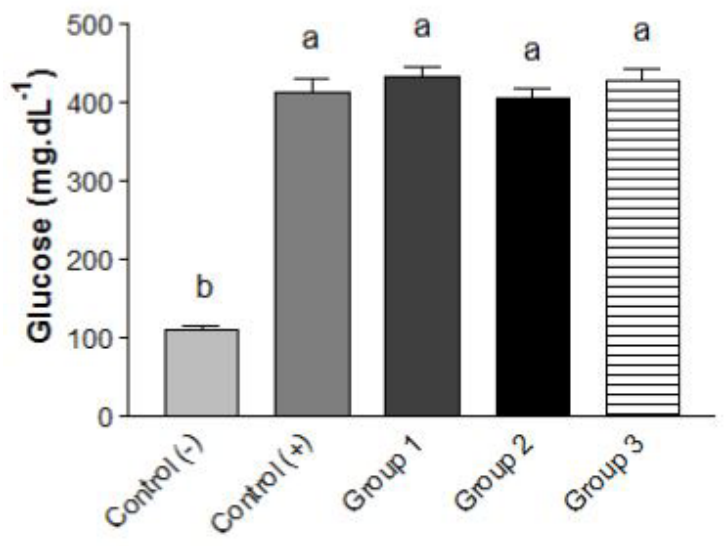

Figure 2. Effect of 30 day administration of prebiotic beverage on alloxan-induced diabetic rat on the following parameters (A) body weight (g); (B) diet consumption (g) and (C) glucose (mg.dL $\left.{ }^{-1}\right)$.

on the glycemia of the diabetic animals in all concentrations tested (see Figure 3).

In the present experiment, was observed a decrease, although with no statistical significance $(P>0.05)$, in the catalase activity (CAT) in the liver of diabetic and non-diabetic animals. Moreover, the prebiotic beverage diet for 30 days caused a significant

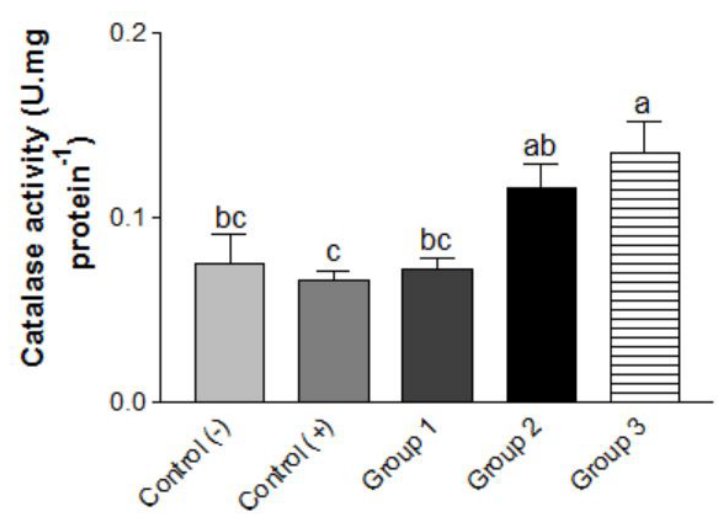

A

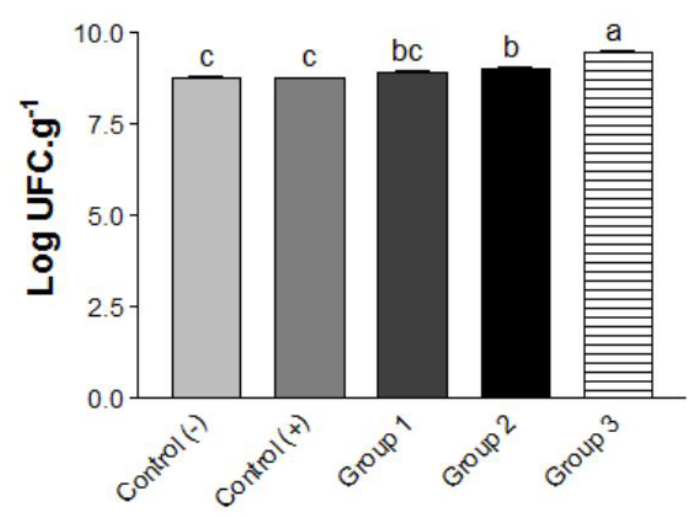

B

Figure 3. Effect of 30 day administration of prebiotic beverage on alloxan-induced diabetic rat on the following parameters (A) catalase activity (U. mg protein ${ }^{-1}$ ) and (B) lactobacilli of ceacal material (log UFC $\cdot \mathrm{g}^{-1}$ of wet sample).

increase in the antioxidant enzyme activity in a dose-dependent manner. As mentioned before, the hyperglycemia is the source of most of the deleterious effects usually associated with Diabetes mellitus, and there is considerable evidence suggesting that chronic elevation of blood glucose concentrations promote auto-oxidation of glucose, and consequently leads to the generation of reactive oxygen species (ROS) (Karunakaran \& Park, 2013; Ceretta et al., 2012). ROS scavenging abilities of endogenous antioxidant defenses - such as catalase, that can be can compensate by exogenous antioxidants (Bajaj \& Khan, 2012). Considering this, we suggested prebiotic beverage antioxidants (phenolic, ascorbic acid and others) can protect the body against free radical-induced damage, being effective in reducing diabetic complications, as mentioned by Bajaj \& Khan (2012) and Karunakaran \& Park (2013).

The results from bacteriological analysis of caecal material are presented in Figure 3. Concentrations (log cfu/g wet sample) of lactobacilli were significantly higher $(P<0.05)$ in samples obtained from animals treated with the prebiotic beverage compared to the positive (diabetic animals) or negative (health animals) control groups, in a dose-dependent manner. The prebiotic effect of yacon are supported by previous studies, showing that FOS from yacon is efficiently metabolized by lactobacilli in vitro 
(Sousa et al., 2015a; Pedreschi et al., 2003) and in vivo using a Sprague-Dawley rats (Campos et al., 2012) and alloxan-induced diabetic Wistar rats (Dionisio et al., 2015).

\section{Conclusion}

In conclusion, the present investigation showed that the prebiotic beverage of yacon and tropical fruits possess considerable concentration of fructooligosaccharides and antioxidant compounds, that could promoted the increase the catalase activity on liver and growth of lactobacilli in the caecal material of alloxan-induced diabetic rats.

\section{Acknowledgements}

The authors would like to thank Brazilian Agricultural Research Corporation (EMBRAPA) and National Council for Scientific and Technological Development (CNPq) and Coordination for the Improvement of Higher Level -or Education- Personnel (CAPES) for the financial support.

\section{References}

Adriano, L. S., Dionísio, A. P., Abreu, F. A. P., Zocolo, G. J., Wurlitzer, N. J., Pinto, C. O., Oliveira, A. C., \& Sampaio, H. A. C. (2019). Yacon syrup reduces postprandial glycemic response to breakfast: a randomized, crossover, double-blind clinical trial. Food Research International, 126, 108682. http://dx.doi.org/10.1016/j.foodres.2019.108682. PMid:31732062.

Aebi, H. (1984). Catalase in vitro. Methods in Enzymology, 105, 121-126. http://dx.doi.org/10.1016/S0076-6879(84)05016-3. PMid:6727660.

Akter, M. S., Oh, S., Eun, J.-B., \& Ahmed, M. (2011). Nutritional compositions and health promoting phytochemicals of camu-camu (Myrciaria dubia) fruit: a review. Food Research International, 44(7), 1728-1732. http://dx.doi.org/10.1016/j.foodres.2011.03.045.

Al-Sheraji, S. H., Ismail, A., Manap, M. Y., Mustafa, S., Yusof, R. M., \& Hassan, F. A. (2013). Prebiotics as functional foods: a review. Journal of Functional Foods, 5(4), 1542-1553. http://dx.doi.org/10.1016/j. jff.2013.08.009.

American Diabetes Association - ADA. (2010). Diagnosis and classification of diabetes mellitus. Diabetes Care, 33(Suppl. 1), 62-69. http://dx.doi.org/10.2337/dc10-S062. PMid:20042775.

Andrews, W. H., Jacobson, A., \& Hammack, T. S. (2016). Salmonella. In Food and Drug Administration - FDA (Ed.), Bacteriological Analytical Manual (BAM) (Chap. 5). Washington: FDA.

Association of Official Analytical Chemists - AOAC. (2005). Official methods of analysis of the Association of Official Analytical Chemists (18th ed). Gaithersburg: AOAC.

Aybar, M. J., Sánchez Riera, A. N., Grau, A., \& Sánchez, S. S. (2001). Hypoglycemic effect of the water extracts of Smallanthus sonchifolius (yacon) leaves in normal and diabetic rats. Journal of Ethnopharmacology, 74(2), 125-132. http://dx.doi.org/10.1016/S0378-8741(00)00351-2. PMid:11167030.

Bajaj, S., \& Khan, A. (2012). Antioxidants and diabetes. Indian Journal of Endocrinology and Metabolism, 16(Suppl. 2), S267-S271. PMid:23565396.

Belwal, T., Devkota, H. P., Hassan, H. A., Ahluwalia, S., Ramadan, M. F., Mocan, A., \& Atanasov, A. G. (2018). Phytopharmacology of acerola (Malpighia spp.) and its potential as functional food. Trends in Food Science \& Technology, 74, 99-106. http://dx.doi.org/10.1016/j. tifs.2018.01.014.

Benzie, I. F., \& Strain, J. J. (1996). The ferric reducing ability of plasma (FRAP) as a measure of "antioxidant power": the FRAP assay. Analytical Biochemistry, 239(1), 70-76. http://dx.doi.org/10.1006/ abio.1996.0292. PMid:8660627.

Brand-Williams, W., Cuvelier, M. E., \& Berset, C. L. W. T. (1995). Use of a free radical method to evaluate antioxidant activity. LebensmittelWissenschaft + Technologie, 28(1), 25-30. http://dx.doi.org/10.1016/ S0023-6438(95)80008-5.

Brasil, Agência Nacional de Vigilancia Sanitaria - ANVISA. (2019). Alegações de propriedade funcional aprovada. Brasília. Retrieved from http://www.agricultura.gov.br/assuntos/inspecao/produtos-vegetal/ legislacao-1/biblioteca-de-normas-vinhos-e-bebidas/alegacoes-depropriedade-funcional-aprovadas_anvisa.pdf

Campos, D., Betalleluz-Pallardel, I., Chirinos, R., Aguilar-Galvez, A., Noratto, G., \& Pedreschi, R. (2012). Prebiotic effects of yacon (Smallanthus sonchifolius Poepp. \& Endl), a source of fructooligosaccharides and phenolic compounds with antioxidant activity. Food Chemistry, 135(3), 1592-1599. http://dx.doi.org/10.1016/j.foodchem.2012.05.088. PMid:22953898.

Carvalho-Silva, L. B., Dionisio, A. P., Pereira, A. C. S., Wurlitzer, N. J., Brito, E. S., Bataglion, G. A., Brasil, I. M., Eberlin, M. N., \& Liu, R. H. (2014). Antiproliferative, antimutagenic and antioxidant activities of a Brazilian tropical fruit juice. Lebensmittel-Wissenschaft + Technologie, 59(2), 1319-1324. http://dx.doi.org/10.1016/j.lwt.2014.04.002.

Ceretta, L. B., Réus, G. Z., Abelaira, H. M., Ribeiro, K. F., Zappellini, G., Felisbino, F. F., Steckert, A. V., Dal-Pizzol, F., \& Quevedo, J. (2012). Increased oxidative stress and imbalance in antioxidant enzymes in the brains of alloxan-induced diabetic rats. Experimental Diabetes Research, 2012, 1-8. http://dx.doi.org/10.1155/2012/302682. PMid:22645603.

Chirinos, R., Galarza, J., Betalleluz-Pallardel, I., Pedreschi, R., \& Campos, D. (2010). Antioxidant compounds and antioxidant capacity of Peruvian camu-camu (Myrciaria dubia (H.B.K.) McVaugh) fruit at different maturity stages. Food Chemistry, 120(4), 1019-1024. http://dx.doi.org/10.1016/j.foodchem.2009.11.041.

Cunha-Santos, E. C. E., Viganó, J., Neves, D. A., Martínez, J., \& Godoy, H. T. (2019). Vitamin C in camu-camu [Myrciaria dubia (H.B.K.) McVaugh]: evaluation of extraction and analytical methods. Food Research International, 115, 160-166. http://dx.doi.org/10.1016/j. foodres.2018.08.031. PMid:30599928.

Delgado, G. T. C., Thomé, R., Gabriel, D. L., Tamashiro, W. M. S. C., \& Pastore, G. M. (2012). Yacon (Smallanthus sonchifolius)-derived fructooligosaccharides improves the immune parameters in the mouse. Nutrition Research, 32(11), 884-892. http://dx.doi.org/10.1016/j. nutres.2012.09.012. PMid:23176799.

Dionisio, A. P., Carvalho-Silva, L. B., Vieira, N. M., Goes, T. S., Wurlitzer, N. J., Borges, M. F., Brito, E. S., Ionta, M., \& Figueiredo, R. W. (2015). Cashew-apple (Anacardium occidentale L.) and yacon (Smallanthus sonchifolius) functional beverage improve the diabetic state in rats. Food Research International, 77, 171-176. http://dx.doi.org/10.1016/j. foodres.2015.07.020.

Dionisio, A. P., Wurlitzer, N. J., Vieira, N. M., Goes, T. S., Modesto, A. L. G., \& Araújo, I. (2013). Raiz tuberosa de yacon (Smallanthus sonchifolius): obtenção de extrato com manutenção das suas propriedades nutricionais e inativação de enzimas de escurecimento (Comunicado Técnico, Vol. 206, pp. 1-5). Brasília: Embrapa Agroindústria Tropical.

Farias, D. P., Araújo, F. F., Neri-Numa, I. A., \& Pastore, G. M. (2019). Prebiotics: trends in food, health and technological applications. 
Trends in Food Science \& Technology, 93, 23-35. http://dx.doi. org/10.1016/j.tifs.2019.09.004.

Feng, P., Weagant, S. D., Grant, M. A., \& Burkhardt, W. (2013). Enumeration of Escherichia coli and the coliform bacteria. In Food and Drug Administration - FDA (Ed.), Bacteriological Analytical Manual (BAM) (4th ed., Chap. 4). Washington: FDA.

Gibson, G. R., Hutkins, R., Sanders, M. E., Prescott, S. L., Reimer, R. A., Salminen, S. J., Scott, K., Stanton, C., Swanson, K. S., Cani, P. D., Verbeke, K., \& Reid, G. (2017). The International Scientific Association for Probiotics and Prebiotics (ISAPP) consensus statement on the definition and scope of prebiotics. National Review, 14(8), 491-502. PMid:28611480.

Horwitz, W., Latimer, J. R., \& George, W. (2010). Official methods of analysis of the association of official analytical chemists (18th ed., Chap. 45, pp. 96-98, Method 999.03). Gaithersburg: AOAC.

Instituto Adolfo Lutz - IAL. (2008). Métodos físico-químicos para análise de alimentos (6. ed.). São Paulo: IAL.

Karunakaran, U., \& Park, K. G. (2013). A systematic review of oxidative stress and safety of antioxidants in diabetes: focus on islets and their defense. Diabetes \& Metabolism Journal, 37(2), 106-112. http://dx.doi. org/10.4093/dmj.2013.37.2.106. PMid:23641350.

Kellow, N. J., Coughlan, M. T., \& Reid, C. M. (2014). Metabolic benefits of dietary prebiotics in human subjects: a systematic review of randomised controlled trials. British Journal of Nutrition, 111(7), 1147-1161. http://dx.doi.org/10.1017/S0007114513003607. PMid:24230488.

Larrauri, J. A., Rupérez, P., \& Saura-Calixto, F. (1997). Effect of drying temperature on the stabilitity of polyphenols and antioxidant activity of red grape pomace peels. Journal of Agricultural and Food Chemistry, 45(4), 1390-1393. http://dx.doi.org/10.1021/jf960282f.

Meilgaard, M., Civille, G. V., \& Carr, B. T. (2006). Sensory evaluation techniques (4th ed.). Florida: CRC Press. http://dx.doi.org/10.1201/ b16452.

Mezadri, T., Villaño, D., Fernández-Pachón, M. S., García-Parrilla, M. C., \& Troncoso, A. M. (2008). Antioxidant compounds and antioxidant activity in acerola (Malpighia emarginata DC.) fruits and derivatives. Journal of Food Composition and Analysis, 21(4), 282-290. http://dx.doi.org/10.1016/j.jfca.2008.02.002.

Miller, N. J., Rice-Evans, C., Davies, M. J., Gopinathan, V., \& Milner, A. (1993). A novel method for measuring antioxidant capacity and its application to monitoring the antioxidant status in premature neonates. Clinical Science, 84(4), 407-412. http://dx.doi.org/10.1042/ cs0840407. PMid:8482045.

Mohanty, D., Misra, S., Mohapatra, S., \& Sahu, P. S. (2018). Prebiotics and synbiotics: recent concepts in nutrition. Food Bioscience, 26, 152-160. http://dx.doi.org/10.1016/j.fbio.2018.10.008.

Obanda, M., Owuor, P. O., \& Taylor, S. J. (1997). Flavanol composition and caffeine content of green leaf as quality potential indicators of Kenyan black teas. Journal of the Science of Food and Agriculture, 74(2), 209-215. http://dx.doi.org/10.1002/(SICI)1097-0010(199706)74:2<209::AIDJSFA789>3.0.CO;2-4.

Ojansivu, I., Ferreira, C. L., \& Salminen, S. (2011). Yacon, a new source of prebiotic oligosaccharides with a history of safe use. Trends in Food Science \& Technology, 22(1), 40-46. http://dx.doi.org/10.1016/j. tifs.2010.11.005.

Park, J., Yang, J., Hwang, B., Yoo, B., \& Han, K. (2009). Hypoglycemic effect of yacon tuber extract and its constituent, chlorogenic acid, in streptozotocin-induced diabetic rats. Biomolecules \& Therapeutics, 17(3), 256-262. http://dx.doi.org/10.4062/biomolther.2009.17.3.256.

Pedreschi, R., Campos, D., Noratto, G., Chirinos, R., \& CisnerosZevallos, L. (2003). Andean yacon root (Smallanthus sonchifolius Poepp. Endl) fructooligosaccharides as a potential novel source of prebiotics. Journal of Agricultural and Food Chemistry, 51(18), 5278-5284. http://dx.doi.org/10.1021/jf0344744. PMid:12926870.

Pereira, A. C. S., Dionísio, A. P., Wurlitzer, N. J., Alves, R. E., Brito, E. S., Silva, A. M. O. E., Brasil, I. M., \& Mancini-Filho, J. (2014). Effect of antioxidant potential of tropical fruit juices on antioxidant enzyme profiles and lipid peroxidation in rats. Food Chemistry, 157, 179-185. http://dx.doi.org/10.1016/j.foodchem.2014.01.090. PMid:24679768.

Pereira, A. C. S., Wurlitzer, N. J., Dionisio, A. P., Soares, M. V. L., Bastos, M. S. R., Alves, R. E., \& Brasil, I. M. (2015). Synergistic, additive and antagonistic effects of fruit mixtures on total antioxidant capacities and bioactive compounds in tropical fruit juices. Archivos Latinoamericanos de Nutricion, 65(2), 119-127. PMid:26817384.

Quigley, E. M. M. (2019). Prebiotics and probiotics in digestive health. Clinical Gastroenterology and Hepatology, 17(2), 333-344. http:// dx.doi.org/10.1016/j.cgh.2018.09.028. PMid:30267869.

Rosso, V. V., \& Mercadante, A. Z. (2007). The high ascorbic acid content is the main cause of the low stability of anthocyanin extracts from acerola. Food Chemistry, 103(3), 935-943. http://dx.doi.org/10.1016/j. foodchem.2006.09.047.

Rufino, M. S. M., Alves, R. E., Brito, E. S., Pérez-Jiménez, J., SauraCalixto, F., \& Mancini-Filho, J. (2010). Bioactive compounds and antioxidant capacities of 18 non-traditional tropical fruits from Brazil. Food Chemistry, 121(4), 996-1002. http://dx.doi.org/10.1016/j. foodchem.2010.01.037.

Satoh, H., Nguyen, M. T. A., Kudoh, A., \& Watanabe, T. (2013). Yacon diet (Smallanthus sonchifolius, Asteraceae) improves hepatic insulin resistence via reducing Trb3 expression in Zucker fa/fa rats. Nutrition \& Diabetes, 3(5), 1-6. http://dx.doi.org/10.1038/nutd.2013.11. PMid:23712282.

Silva, M. F. G., Dionísio, A. P., Carioca, A. A. F., Adriano, L. S., Pinto, C. O., Abreu, F. A. P., Wurlitzer, N. J., Araújo, I. M., Garruti, D. S., \& Pontes, D. F. (2017). Yacon syrup: food applications and impact on satiety in healthy volunteers. Food Research International, 100(Pt 1), 460-467. http://dx.doi.org/10.1016/j.foodres.2017.07.035. PMid:28873709.

Sousa, S., Pinto, J., Pereira, C., Malcata, F. X., Pacheco, M. T. B., Gomes, A. M., \& Pintado, M. (2015b). In vitro evaluation of yacon (Smallanthus sonchifolius) tuber flour prebiotic potential. Food and Bioproducts Processing, 95, 96-105. http://dx.doi.org/10.1016/j.fbp.2015.04.003.

Sousa, S., Pinto, J., Rodrigues, C., Gião, M., Pereira, C., Tavaria, F., Malcata, F. X., Gomes, A., Bertoldo Pacheco, M. T., \& Pintado, M. (2015a). Antioxidant properties of sterilized yacon (Smallanthus sonchifolius) tuber flour. Food Chemistry, 188, 504-509. http://dx.doi. org/10.1016/j.foodchem.2015.04.047. PMid:26041224.

Souza, F. P., Balthazar, C. F., Guimarães, J. T., Pimentel, T. C., Esmerino, E. A., Freitas, M. Q., Raices, R. S. L., Silva, M. C., \& Cruz, A. G. (2019). The addition of xyloligoosaccharide in strawberry-flavored whey beverage. Lebensmittel-Wissenschaft + Technologie, 109, 118122. http://dx.doi.org/10.1016/j.lwt.2019.03.093.

Yamaguchi, K. K. L., Pereira, L. F. R., Lamarão, C. V., Lima, E. S., \& Veiga-Junior, V. F. (2015). Amazon acai: Chemistry and biological activities: a review. Food Chemistry, 179, 137-151. http://dx.doi. org/10.1016/j.foodchem.2015.01.055. PMid:25722148. 